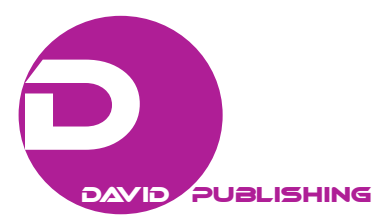

\title{
Consumer Attitudes Towards Private Shopping Sites in Turkey
}

\author{
Burcu İnci \\ Nisantasi University, Istanbul, Turkey
}

\begin{abstract}
Private shopping sites (PSSs) business model is developing rapidly both in the world and in Turkey since 2000s. However, studies related consumer attitudes towards private shopping sites in Turkey are limited in the literature. So, the main aim of this paper is revealing variables that affect attitudes of PSSs customers in Turkey and conceptualizing these variables within the scope of a model that depends on Technology Acceptance Model (TAM). In this descriptive study, research population includes all of the consumers who made at least one shopping from PSSs in Turkey and "snowball sampling method" is used. In consequence of an online survey application 409 questionnaires are analyzed. As a result of regression analysis, all of the 14 hypotheses are accepted. In conclusion all of the variables in the model (product quality, delivery service, system quality, information quality, service quality, perceived usefulness, perceived ease of use, compatibility, privacy, and security) have significant relations with consumer attitudes. The most important variables in building positive attitudes towards PSSs are perceived usefulness and compatibility. Conversely the lowest variance prediction percentage belongs to privacy variable.
\end{abstract}

Keywords: Technology Acceptance Model (TAM), online shopping, private shopping sites (PSSs), consumer attitudes, PSSs in Turkey

\section{Introduction}

The findings of Turkstat (Turkish Statistical Institute)'s Information and Communication Technology (ICT) Usage Survey on Households and Individuals (2016) show the rapid growth of Internet usage and online shopping in Turkey. Some of those striking statistics are shared below (http://www.turkstat.gov.tr/):

- Internet usage of individuals aged $16-74$ is $61.2 \%$, while it was $55.9 \%$ in 2015 . Proportion of male that use Internet is $70.5 \%$, while this proportion is $51.9 \%$ for female.

- $76.3 \%$ of households have access to the Internet.

- $96.9 \%$ of households have mobile phone (including smart phones); $22.9 \%$ of households have desktop computer; $36.4 \%$ of households have portable computer; and $29.6 \%$ of households have tablet computer.

- $82.4 \%$ of individuals used internet for participating in social networks. This proportion was followed by watching video content from sharing services (74.5\%), reading online news, newspapers, and news magazines (69.5\%), seeking health-related information (65.9\%), finding information about goods and services (65.5\%), and listening to music $(63.7 \%)$.

- $94.9 \%$ of individuals who used the Internet in the first quarter of 2016, used the Internet almost every day or at least once a week (regularly Internet use).

Burcu İnci, assist. prof., Faculty of Economics and Administrative Sciences, Department of Business, Nisantasi University, Istanbul, Turkey.

Correspondence concerning this article should be addressed to Burcu İnci, Nisantasi University, Sadabad Kampüsü, Hasbahçe Cad. No. 8834406 Kağıthane, İstanbul, Turkey. 
- The percentage of ordering or buying goods or services over the Internet for private purposes was $34.1 \%$ and this proportion increased $1 \%$ compared to 2015 .

- $60 \%$ of Internet customers bought clothes and sports goods; $29.7 \%$ of that bought travel arrangements (transport tickets, renting a car etc.); $25.8 \%$ of that bought household goods (e.g. furniture, toys, etc.; excluding consumer electronics); $21 \%$ of that bought electronic equipment (mobile phones, cameras, radio, TV, DVD player, etc.), and $19.8 \%$ of that bought food or groceries.

- $24.9 \%$ of individuals who bought goods or services over the Internet in the last 12 months (April 2015-March 2016) encountered problems. The most common problems were "speed of delivery longer than indicated" with $44.9 \%$ and "wrong or damaged goods/services delivered" with $42.1 \%$.

TÜBİSAD (Informatics Industry Association in Turkey) prepared "the Turkey's E-trade Industry-2015" report with the mutual efforts of the project partners that are ETID (Association of E-Commerce Operators), Deloitte Turkey and Comscore. In this report, B2B e-trade is not included, and it only covers B2C and C2C e-trade. Some of the important findings are being shared below (Table 1) (https://www2.deloitte.com/).

Table 1

Country Comparisions According to "Turkey's E-Trade Industry-2015 Report"

\begin{tabular}{|c|c|c|c|c|c|c|}
\hline & Country & $\begin{array}{l}\text { Online retailing/ } \\
\text { total retailing }(\%)\end{array}$ & $\begin{array}{l}\text { Internet } \\
\text { penetration }(\%)\end{array}$ & $\begin{array}{l}\text { Online shoppers } \\
(\%)\end{array}$ & $\begin{array}{l}\text { Income per capita } \\
\text { (KUSD) }\end{array}$ & $\begin{array}{l}\text { Population } \\
\text { (milion) }\end{array}$ \\
\hline \multirow{7}{*}{$\begin{array}{l}\text { Developed } \\
\text { countries }\end{array}$} & England & 12.6 & 92 & 77 & 41.2 & 65.1 \\
\hline & USA & 9.2 & 88 & 66 & 55.8 & 323.7 \\
\hline & Germany & 7.9 & 88 & 74 & 46.9 & 81.8 \\
\hline & French & 6.8 & 86 & 64 & 41.2 & 66.7 \\
\hline & Japan & 7.2 & 91 & 55 & 38.1 & 127.0 \\
\hline & Spain & 3.3 & 80 & 57 & 34.8 & 46.4 \\
\hline & Italy & 2.6 & 65 & 49 & 35.7 & 60.8 \\
\hline \multirow{7}{*}{$\begin{array}{l}\text { Developing } \\
\text { countries }\end{array}$} & China & 9.7 & 51 & 44 & 14.1 & $1,376.0$ \\
\hline & Poland & 6.8 & 71 & 53 & 26.5 & 38.4 \\
\hline & Brazil & 4.1 & 64 & 44 & 15.6 & 206.2 \\
\hline & Russia & 3.8 & 71 & 48 & 25.4 & 146.6 \\
\hline & India & 1.9 & 27 & 23 & 6.2 & $1,289.7$ \\
\hline & $\begin{array}{l}\text { Turkey } \\
(2014)\end{array}$ & 1.6 & 54 & 33 & 19.7 & 77.7 \\
\hline & $\begin{array}{l}\text { Turkey } \\
(2015)\end{array}$ & 2.0 & 62 & 39 & 20.4 & 78.7 \\
\hline
\end{tabular}

https://www2.deloitte.com/content/dam/Deloitte/tr/Documents/technology-media-telecommunications/TUBISAD-Eticaret-2015-S unum.pdf.

- Turkey's e-trade market size was 14.0 billion TRY in 2013. It experienced 35\% growth in 2014 and reached 18.9 billion TRY and in 2015 with a $31 \%$ growth, it captured 24.7 billion TRY.

- 2.5 billion TRY comes from online legal betting sites while 8.9 billion TRY comes from vacation and traveling spendings in Turkey's e-trade industry. When we look at the retailing spendings 4.8 billion TRY belongs to multi-channel retailing systems and 8.5 billion TRY belongs to online retailing systems.

- Vacation and traveling receive the highest $36 \%$ share inside 24.7 billion TRY e-trade industry with 129 sites. Online retailing follows it with $34 \%$ share and 365 sites. The share of multi-channel retailing systems is $20 \%$ with 385 sites and lastly legal betting sites cover $10 \%$ share with six sites. 
- When we look at the categories in more detail, highest spending goes to multi-channel vacation and traveling ( 7.6 billion TRY), online marketplaces ( 3.8 billion TRY), legal betting ( 2.5 billion TRY), online with mulptile categories (2.2 billion TRY), online private shopping (1.8 billion TRY), and multi-channel electronics (1.8 billion TRY) follow it respectively.

- In England, USA, Germany, French, Japan, Spain, and Italy which are called developed countries, the avarage of online retailing/total retailing is $7.1 \%$ while this number is $5.1 \%$ in China, Poland, Brazil, Russia, and India which are called developing countries. According to 2015 data, in Turkey online retailing only covers the $2.0 \%$ of total retailing. In the following tables, more detailed information is being presented in order to see the place of Turkey based on online shopping.

All these numbers show that there is a great potential for online shopping in Turkey. Private shopping sites (PSSs) are one of the most popular online shopping models in Turkey. However, studies related consumer attitudes towards private shopping sites in Turkey are limited in the literature. So the aim of this paper is revealing variables that affect attitudes of PSSs customers in Turkey and conceptualizing these variables within the scope of a model that depends on Technology Acceptance Model (TAM).

\section{Literature Review}

\section{Private Shopping Sites (PSSs)}

PSSs work from business to consumer (B2C) and they offer customers huge discounts, attractive product variety, and some well-known luxury brands. In these sites generally fashion products are sold within a limited 24-48 hours timeline. There is a membership requirement for entering the PSSs. Some of them developed a different kind of membership systems and by giving rewards to their most profitable customers they try to earn their loyalty. For instance the most profitable customers may have the opportunity of reaching the products on sale one hour earlier than the other customers and they can buy the limited products before running out (Martinez \& Kim, 2012). PSS business model has been invented by French market leader Vente-privee.com in 2001 and spreaded to the world market rapidly. In 2010, Amazon bought Spanish Buy-VIP PSS and eBay bought German Brands4friends PSS. Vente-privee.com and American Express started to a joint attempt in 2011. Gilt.com entered market in 2007 and it is in competition with the other American PSSs such as Ruelala.com, HauteLook.com, and Ideeli.com. These sites usually focus on apparel, but some of them also sell cosmetics, elektronics, and travelling goods etc. The main goal is creating a "smart shopper" feeling and as a result, prompting buying motives (Ayadi, Giraud, \& Gonzalez, 2013).

The main difference between PSSs and the other online retailers is their closed-loop shopping system. In other words, only members can enter PSSs. Additionally the content of these sites cannot be seen in search engines and this means a privilege for the PSSs, their suppliers, and customers. Besides all of the components of PSSs are designed by considering "luxury" concept in order to create a luxury position in consumers' minds. Campaigns based on limited products and time trigger customers' impulsive buying behavior (Akalın, 2011). In the past consumers who want to find luxury products with below market prices needed to live in a central city of fashion and follow discounted sales days. However, today with the help of PSSs, consumers have this opportunity independently from where they live. Besides, owing to PSSs, firms conquer fear of damaging their brand names when they sell products with below market prices. This type of online retailing provides firms for getting rid of their excess inventories without damaging brand images. Moreover PSSs bring advantages such as excitiment and adrenalin, and luxury products become highly delighted with the shopping (Martinez, 2011). 
In Turkey, the first PSS named Markafoni opened in 2008. Then Otto Group opened Turkey's second PSS named Limango in 2009. PSSs have given acceleration to Turkish online retailing industry. In 2010 new entrants such as Trendyol, Unnado, and Vipdükkan got involved in the PSS industry. After 2011 this trend kept on rising with new PSSs such as Morhipo, Daybuyday, Markareyon, and Perabulvarı (http:/eticaretmag.com/). However after some time supply, it exceeded the demand and as a result some of the PSSs were obliged to being closed.

\section{Technology Acceptance Model (TAM)}

According to TAM developed by Davis (1986), a potential user's general attitude towards using a spesific system is a function of two main beliefs that are "perceived usefulness" and "perceived ease-of-use". Perceived usefulness is the degree to which a potential user believes that using a particular system would enhance his or her job performance. Perceived ease-of-use is the degree to which a potential user believes that using a particular system would be free from effort (Davis, 1989). TAM is formulized by using Theory of Reasoned Action (TRA) as a theoretical ground. Figure 1 summarizes the TAM model (Davis, Bagozzi, \& Warshaw, 1989).

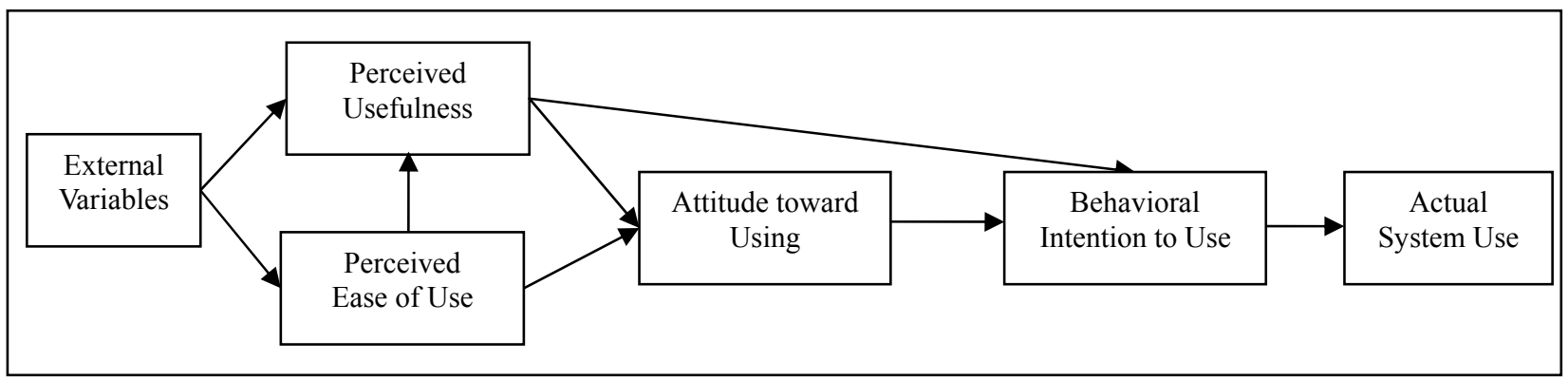

Figure 1. Technology Acceptance Model (TAM).

Although Theory of Reasoned Action (TRA) is developed for explaining almost every kind of human behavior, the goal of TAM is explaining the determinants of computer technologies acceptence (Chen, Gillenson, \& Sherrell, 2002). Research model of this study depends on TAM. However since this model was developed in 1986, its goal was not explaining the online shopping attitudes and behaviors. So in this study, other three studies (Lin, 2007; Vijayasarathy, 2004; Ahn, Ryu, \& Han, 2004) that associate TAM with online shopping attitudes and behaviors are also reviwed. However since the aim of this study is only analyzing the attitudes towards PSSs, only attitude dimensions within these three studies are evaluated.

Lin (2007) compared two versions of TAM and Theory of Planned Behavior (TPB) for analyzing which model can best predict online shopping attiude, intent, and behavior. She collected data from 297 customers who shop from online book stores and compared the models by using structural equation modeling. Eventually she added compatibility: an additional determinant of attitude besides ease of use and usefulness in an augmented TAM. Vijayasarathy (2004) developed additional constructs to the original model in order to increase the strenght of TAM in predicting online shopping behavior and as determinants of attitude besides perceived ease of use and perceived usefulness, compatibility, privacy, and security are included in an augmented TAM. In order to test this model, he collected data from 281 consumers. According to data analysis results, perceived ease of use, perceived usefulness, compatibility, and security are found as important determinants of online shopping attitude (privacy is not found). Ahn, Ryu, and Han (2004) researched online and offline characteristics of online stores and the relation between these characteristics and customer 
acceptence behaviors. Online characteristics were system quality, information quality, and service quality while offline characteristics were product quality and delivery service. They applied an online survey to 932 users and results showed that TAM is relevant in predicting online store acceptence. Also online and offline characteristics have positive impacts on users' acceptence. According to their result both online and offline characteristics have large impacts on attitude. However while offline characteristics have only impacts on perceived usefulness, online characteristics have impacts on both perceived usefulness and perceived ease of use.

\section{Research Model and Hypotheses}

In this study, research model which can be seen from Figure 2, has 11 sub-scales measured with 5-point Likert scale and their items are derived from the literature (İnci, 2014).

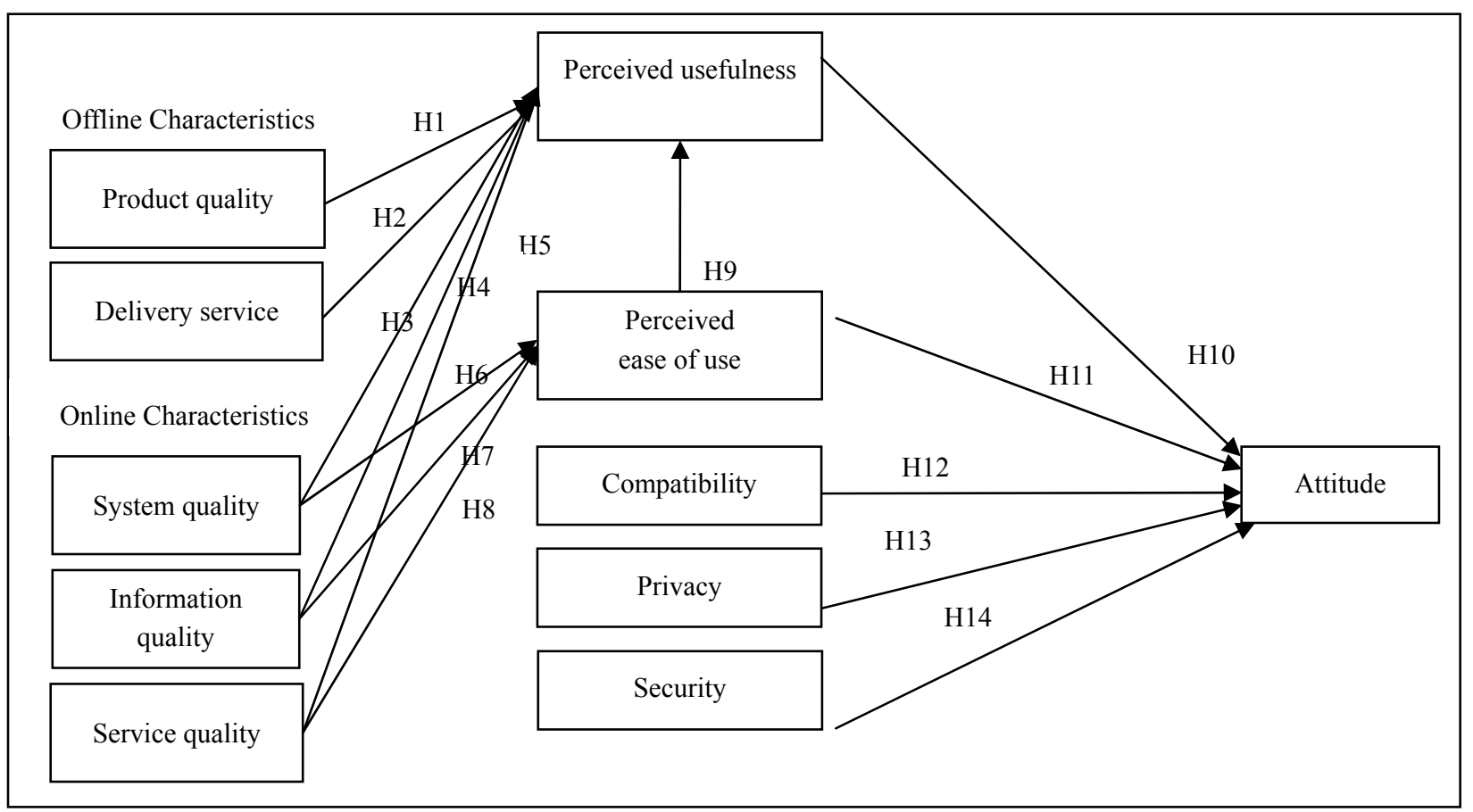

Figure 2. Research model.

H1: There is a statistically significant relationship between product quality (one of PSS's offline characteristic) and PSS's perceived usefulness.

H2: There is a statistically significant relationship between delivery service (one of PSS's offline characteristic) and PSS's perceived usefulness.

H3: There is a statistically significant relationship between system quality (one of PSS's online characteristic) and PSS's perceived usefulness.

H4: There is a statistically significant relationship between information quality (one of PSS's online characteristic) and PSS's perceived usefulness.

H5: There is a statistically significant relationship between service quality (one of PSS's online characteristic) and PSS's perceived usefulness.

H6: There is a statistically significant relationship between system quality (one of PSS's online characteristic) and PSS's perceived ease of use. 
H7: There is a statistically significant relationship between information quality (one of PSS's online characteristic) and PSS's perceived ease of use.

H8: There is a statistically significant relationship between service quality (one of PSS's online characteristic) and PSS's perceived ease of use.

H9: There is a statistically significant relationship between PSS's perceived ease of use and PSS's perceived usefulness.

H10: There is a statistically significant relationship between PSS's perceived usefulness and consumers's attitudes towards shopping from PSS.

H11: There is a statistically significant relationship between PSS's perceived ease of use and consumers's attitudes towards shopping from PSS.

H12: There is a statistically significant relationship between consumers' beliefs on PSS's compatibility and consumers' attitudes towards shopping from PSS.

H13: There is a statistically significant relationship between consumers' beliefs on the privacy provided by PSS and consumers' attitudes towards shopping from PSS.

H14: There is a statistically significant relationship between consumers' beliefs on PSS's security and consumers' attitudes towards shopping from PSS.

\section{Research Methods}

\section{Aim of the Research}

Private shopping site business model develops rapidly both in the world and in Turkey since 2000s. However, studies related consumer attitudes towards private shopping sites are limited in the literature. So, the main aim of this paper is exhibiting variables affecting attitudes of customers using private shopping sites and conceptualizing these variables within the scope of a model that depends on Technology Acceptance Model (TAM).

\section{Sampling and Data Collection}

In this study research population includes all of the consumers who made at least one shopping from private shopping sites in Turkey. According to 2014 data, Markafoni which is Turkey's first and leader PSS, has 7.2 million members (http://www.superbrandsturkey.com/) and there are many other PSSs in Turkey, so research population consists of millions of people. In order to reach a representative sample, snowball sampling method is used considering time constraints. Unfortunately it was impossible to find a full list of PSS shoppers in Turkey, so researcher firstly sent the survey to known friends by their shopping from PSSs. Then these friends were asked for sending the survey to the people who they know as shopping from PSSs. With the help of this cycle, all PSS shoppers that can be reached were included in the sample. Because of researching online consumer attitudes, it is thought that applying the survey in online environment was more appropriate. This online survey was created on surveymonkey.com and its link was spreaded by social networks (Facebook, Twitter, and Linkedin) and e-mail. Totally 612 participants filled in the questionnaire between 15 January 2014 and 07 March 2014. One hundred and sixty six questionnaires with deficient answers, three questionnaires with periodically same answers, and 34 questionnaires in which participants perceived PSSs as other online sites were not included in the analysis. As a result, 409 questionnaires are evaluated with a $66.8 \%$ response rate. 


\section{Research Results}

In this section findings about participants' demografic characteristics, reliability analysis of the scales, factor analysis, descriptive statistics of the scale items, and regression analysis will be presented respectively. As it can be seen from Table 2, most of the participants are women (77.8\%); 57.5\% of of the participants are between $25-34$ ages; and $75.8 \%$ of the participants are under 35 years old; $65 \%$ of the participants have postgraduate degree and $34 \%$ of the participants have bachelor's degree. Snowball sampling method caused such a demographic profile. According to references, reaching people with similar characteristics was inevitable. Additionally most of the participants are from İstanbul (53.5\%), İzmir (9.8\%), and Ankara (8.8\%). According to Turkstat 2016 data (2016), 18.6\% of Turkey's population live in İstanbul and it is the most crowded city of the country. Ankara (6.7\%) is the second, and Izmir $(5.3 \%)$ is the third most crowded cities (http://www.tuik.gov.tr/). When we look at the income levels and marital status, it is seen that none of the category is dominant. Most of the participants work in private sector (45\%) and public sector employees follow them $(35.9 \%)$.

Reliability of the scales is analyzed by Cronbach's Alpha values and Item-Total Correlations which are shown in Table 3. According to Büyüköztürk (2011), Cronbach's Alpha values as 0.70 or higher are generally sufficient for the reliability. Büyüköztürk (2011) also says that items with 0.20 or higher Item-Total Correlations are reliable. So it can be said that scales used for this study are highly reliable.

Table 2

Frequencies and Percentages of Participants' Demografic Characteristicsm

\begin{tabular}{|c|c|c|c|}
\hline \multicolumn{2}{|c|}{ Demografic characteristics } & \multirow{2}{*}{$\begin{array}{l}\text { Frequency (n) } \\
318\end{array}$} & \multirow{2}{*}{$\begin{array}{l}\text { Percentage }(\%) \\
77.8\end{array}$} \\
\hline Gendor & Woman & & \\
\hline Gender & Man & 91 & 22.2 \\
\hline \multirow{4}{*}{ Age } & $18-24 \mathrm{~m}$ & 75 & 18.3 \\
\hline & $25-34$ & 235 & 57.5 \\
\hline & $35-44$ & 84 & 20.5 \\
\hline & 45 and above & 15 & 3.7 \\
\hline \multirow{2}{*}{ Marital status } & Unmarried & 231 & 56.5 \\
\hline & Married & 178 & 43.5 \\
\hline \multirow{4}{*}{ Education } & High school & 10 & 2.4 \\
\hline & Bachelor's degree & 139 & 34.0 \\
\hline & Master's degree & 120 & 29.3 \\
\hline & Doctorate degree & 140 & 34.2 \\
\hline \multirow{4}{*}{ Residence } & İstanbul & 219 & 53.5 \\
\hline & İzmir & 40 & 9.8 \\
\hline & Ankara & 36 & 8.8 \\
\hline & Others & 114 & 27.9 \\
\hline \multirow{8}{*}{ Income } & 1,500 TRY and below & 14 & 3.4 \\
\hline & 1,501-2,500 TRY & 65 & 15.9 \\
\hline & $2,501-3,500 \mathrm{TRY}$ & 69 & 16.9 \\
\hline & 3,501-4,500 TRY & 54 & 13.2 \\
\hline & 4,501-5,500 TRY & 65 & 15.9 \\
\hline & 5,501-6,500 TRY & 59 & 14.4 \\
\hline & $6,501-7,500 \mathrm{TRY}$ & 32 & 7.8 \\
\hline & 7,500 TRY and above & 51 & 12.5 \\
\hline
\end{tabular}


Table 2 continued

\begin{tabular}{llll}
\hline Demografic characteristics & & Frequency (n) & Percentage (\%) \\
\hline \multirow{3}{*}{ Occupation } & Self-employment & 17 & 4.2 \\
& Private sector employee & 184 & 45.0 \\
& Public sector employee & 147 & 35.9 \\
& Student & 49 & 12.0 \\
& Retired/housewife/unemployed & 12 & 2.9 \\
\hline
\end{tabular}

Table 3

Reliability Analysis of the Scales

\begin{tabular}{|c|c|c|c|c|c|c|c|}
\hline Scale & Item & $\begin{array}{l}\text { Item-total } \\
\text { correlation }\end{array}$ & $\begin{array}{l}\text { Cronbach's } \\
\text { Alpha }(\alpha)\end{array}$ & Scale & Item & $\begin{array}{l}\text { Item-total } \\
\text { correlation }\end{array}$ & $\begin{array}{l}\text { Cronbach's } \\
\text { Alpha }(\alpha)\end{array}$ \\
\hline \multirow{6}{*}{$\begin{array}{l}\text { Perceived } \\
\text { usefulness }\end{array}$} & pu1 & 0.70 & \multirow{6}{*}{0.84} & \multirow{6}{*}{ Service quality } & seq1 & 0.66 & \multirow{6}{*}{0.89} \\
\hline & pu2 & 0.71 & & & seq2 & 0.77 & \\
\hline & pu3 & 0.57 & & & seq3 & 0.80 & \\
\hline & pu4 & 0.61 & & & seq4 & 0.69 & \\
\hline & pu5 & 0.71 & & & seq5 & 0.67 & \\
\hline & pu6 & 0.44 & & & seq6 & 0.71 & \\
\hline \multirow{3}{*}{$\begin{array}{l}\text { Perceived ease of } \\
\text { use }\end{array}$} & peu1 & $0.83 * *$ & \multirow{3}{*}{$0.90^{*}$} & \multirow{3}{*}{ Product quality } & $\mathrm{pq} 1$ & 0.49 & \multirow{3}{*}{0.68} \\
\hline & peu2 & $0.83 * *$ & & & pq2 & 0.41 & \\
\hline & peu3 & 0.20 (pi) & & & $\mathrm{pq} 3$ & 0.59 & \\
\hline \multirow{2}{*}{ Compatibility } & $\mathrm{c} 1$ & 0.78 & \multirow{2}{*}{0.88} & \multirow{5}{*}{ Delivery service } & ds 1 & 0.65 & \multirow{5}{*}{0.84} \\
\hline & $\mathrm{c} 2$ & 0.78 & & & ds2 & 0.69 & \\
\hline \multirow{2}{*}{ Privacy } & $\mathrm{p} 1$ & 0.70 & \multirow{2}{*}{0.83} & & $\mathrm{ds} 3$ & 0.69 & \\
\hline & $\mathrm{p} 2$ & 0.70 & & & ds4 & 0.61 & \\
\hline \multirow{2}{*}{ Security } & s1 & 0.69 & \multirow{2}{*}{0.81} & & ds 5 & 0.62 & \\
\hline & s2 & 0.69 & & \multirow{9}{*}{$\begin{array}{l}\text { Information } \\
\text { quality }\end{array}$} & iq1 & 0.66 & \multirow{9}{*}{0.92} \\
\hline \multirow{8}{*}{ System quality } & syq1 & 0.71 & \multirow{8}{*}{0.88} & & iq2 & 0.80 & \\
\hline & syq2 & 0.67 & & & iq3 & 0.82 & \\
\hline & syq3 & 0.56 & & & iq4 & 0.78 & \\
\hline & syq4 & 0.64 & & & iq5 & 0.78 & \\
\hline & syq5 & 0.60 & & & iq6 & 0.79 & \\
\hline & syq 6 & 0.75 & & & iq7 & 0.76 & \\
\hline & syq 7 & 0.61 & & & iq8 & 0.45 & \\
\hline & syq8 & 0.63 & & & & & \\
\hline \multirow{6}{*}{ Attitude } & a1 & 0.76 & \multirow{6}{*}{0.86} & & & & \\
\hline & $\mathrm{a} 2$ & 0.77 & & & & & \\
\hline & a3 & 0.83 & & & & & \\
\hline & a4 & 0.69 & & & & & \\
\hline & a5 & 0.30 & & & & & \\
\hline & a6 & 0.66 & & & & & \\
\hline
\end{tabular}

Notes. pi: Problematical item; *: Cronbach's Alpha when the problematical item extracted; **: Item-total correlation when the problematical item extracted.

Also exploratory factor analysis has been made for the 11 scales and principle components of scales, explained variances, and factor loadings of items are determined. According to findings all of the items in all scales are aggregated under a single component. So there was no need of rotation. Factor analysis results are shown in Table 4 and according to these results, items are under a single factor in their scale and these factors meet the explained variances sufficiently. 
Table 4

Factor Analysis of the Scales

\begin{tabular}{|c|c|c|c|c|c|c|c|}
\hline Scale & Item & $\begin{array}{l}\text { Factor } \\
\text { loading }\end{array}$ & $\begin{array}{l}\text { Explained } \\
\text { variance }\end{array}$ & Scale & Item & $\begin{array}{l}\text { Factor } \\
\text { loading }\end{array}$ & $\begin{array}{l}\text { Explained } \\
\text { variance }\end{array}$ \\
\hline \multirow{6}{*}{$\begin{array}{l}\text { Perceived } \\
\text { usefulness }\end{array}$} & pu1 & 0.82 & \multirow{6}{*}{$57 \%$} & \multirow{6}{*}{ Service quality } & seq1 & 0.76 & \multirow{6}{*}{$66 \%$} \\
\hline & $\mathrm{pu} 2$ & 0.83 & & & seq2 & 0.86 & \\
\hline & pu3 & 0.71 & & & seq3 & 0.87 & \\
\hline & pu4 & 0.74 & & & seq4 & 0.79 & \\
\hline & pu5 & 0.82 & & & seq5 & 0.77 & \\
\hline & pu6 & 0.57 & & & seq6 & 0.81 & \\
\hline \multirow{3}{*}{$\begin{array}{l}\text { Perceived ease of } \\
\text { use }\end{array}$} & peul & $0.96 * *$ & \multirow{3}{*}{$91 \% *$} & \multirow{3}{*}{ Product quality } & $\mathrm{pq} 1$ & 0.78 & \multirow{3}{*}{$61 \%$} \\
\hline & peu2 & $0.96 * *$ & & & $\mathrm{pq} 2$ & 0.71 & \\
\hline & peu3 & 0.39 (pi) & & & $\mathrm{pq} 3$ & 0.85 & \\
\hline \multirow{2}{*}{ Compatibility } & $\mathrm{c} 1$ & 0.94 & \multirow{2}{*}{$89 \%$} & \multirow{5}{*}{ Delivery service } & $\mathrm{ds} 1$ & 0.80 & \multirow{5}{*}{$62 \%$} \\
\hline & $\mathrm{c} 2$ & 0.94 & & & ds2 & 0.83 & \\
\hline \multirow{2}{*}{ Privacy } & p1 & 0.92 & \multirow{2}{*}{$85 \%$} & & ds 3 & 0.82 & \\
\hline & $\mathrm{p} 2$ & 0.92 & & & ds4 & 0.74 & \\
\hline \multirow{2}{*}{ Security } & s1 & 0.92 & \multirow{2}{*}{$84 \%$} & & ds5 & 0.75 & \\
\hline & $\mathrm{s} 2$ & 0.92 & & \multirow{9}{*}{$\begin{array}{l}\text { Information } \\
\text { quality }\end{array}$} & iq1 & 0.73 & \multirow{9}{*}{$65 \%$} \\
\hline \multirow{8}{*}{ System quality } & syq1 & 0.80 & \multirow{8}{*}{$55 \%$} & & iq2 & 0.86 & \\
\hline & syq2 & 0.77 & & & iq3 & 0.87 & \\
\hline & syq3 & 0.66 & & & iq4 & 0.86 & \\
\hline & syq4 & 0.72 & & & iq5 & 0.85 & \\
\hline & syq5 & 0.70 & & & iq6 & 0.87 & \\
\hline & syq6 & 0.83 & & & iq7 & 0.82 & \\
\hline & syq7 & 0.69 & & & iq8 & 0.53 & \\
\hline & syq 8 & 0.72 & & & & & \\
\hline \multirow{6}{*}{ Attitude } & a1 & 0.87 & \multirow{6}{*}{$63 \%$} & & & & \\
\hline & $\mathrm{a} 2$ & 0.87 & & & & & \\
\hline & a3 & 0.91 & & & & & \\
\hline & $\mathrm{a} 4$ & 0.82 & & & & & \\
\hline & a5 & 0.40 & & & & & \\
\hline & $\mathrm{a} 6$ & 0.78 & & & & & \\
\hline
\end{tabular}

Notes. pi: Problematical item; *: Explained variance when the problematical item extracted; **: Factor loading when the problematical item extracted.

All of the questions in the survey are measured with 5-point Likert scale in which 1 means "Totally disagree" while 5 means "Totally agree". So low scores show negative attitudes and vice versa. Table 5 presents descriptive statistics of the scales and Table 6 descriptive statistics of the scale items.

Table 5

Descriptive Statistics of the Scales

\begin{tabular}{llll}
\hline Scale & Item number & Mean & Standard deviation \\
\hline Perceived ease of use & 3 & 4.03 & 0.84 \\
System quality & 8 & 3.79 & 0.56 \\
Attitude & 6 & 3.71 & 0.69 \\
Delivery service & 5 & 3.67 & 0.73 \\
Perceived usefulness & 6 & 3.64 & 0.73 \\
Product quality & 3 & 3.61 & 0.66 \\
\hline
\end{tabular}


Table 5 continued

\begin{tabular}{llll}
\hline Scale & Item number & Mean & Standard deviation \\
\hline Service quality & 6 & 3.53 & 0.68 \\
Information quality & 8 & 3.45 & 0.69 \\
Compatibility & 2 & 3.43 & 0.92 \\
Security & 2 & 3.23 & 0.82 \\
Privacy & 2 & 3.11 & 0.92 \\
\hline
\end{tabular}

Table 6

Descriptive Statistics of the Scale Items (My favourite PSS*: Most frequently used PSS by the participant)

\begin{tabular}{|c|c|c|c|}
\hline Scale & Scale items & Mean & Standard deviation \\
\hline \multirow{6}{*}{ Attitude } & a1: I feel that using PSSs is a good idea & 3.73 & 0.84 \\
\hline & a2: I feel that using PSSs is a reasonable idea & 3.87 & 0.87 \\
\hline & a3: I feel that using PSSs is a positive idea & 3.79 & 0.84 \\
\hline & a4: I feel that using PSSs is an attractive idea & 3.66 & 0.91 \\
\hline & a5: I feel that using PSSs includes a kind of trickery (Reverse coding) & 3.55 & 1.02 \\
\hline & a6: I like using PSSs & 3.69 & 0.89 \\
\hline \multirow{6}{*}{$\begin{array}{l}\text { Perceived } \\
\text { usefulness }\end{array}$} & pu1: Using PSSs facilitates making comparison shopping & 3.94 & 0.88 \\
\hline & pu2: Using PSSs provides achieving useful shopping information & 3.68 & 0.93 \\
\hline & pu3: Using PSSs provides time saving & 3.98 & 0.96 \\
\hline & pu4: Using PSSs provides money saving & 3.47 & 1.04 \\
\hline & pu5: Using PSSs provides making better buying decision & 3.43 & 1.01 \\
\hline & pu6: Using PSSs provides following the fashion & 3.36 & 1.04 \\
\hline \multirow{3}{*}{$\begin{array}{l}\text { Perceived } \\
\text { ease of use }\end{array}$} & peu1: Learning how to use PSSs is easy for me & 4.08 & 0.84 \\
\hline & peu2: Becoming professional at using PSSs is easy for me & 3.99 & 0.92 \\
\hline & $\begin{array}{l}\text { peu3: Using PSSs requires too much mental effort (Reverse coding) } \\
\text { (After factor and reliability analysis, this item is extracted from its scale) }\end{array}$ & 3.90 & 0.97 \\
\hline \multirow{2}{*}{ Compatibility } & c1: Using PSSs is very compatible to my lifestyle & 3.45 & 0.99 \\
\hline & c2: Using PSSs is very compatible for my shopping needs & 3.42 & 0.97 \\
\hline \multirow{2}{*}{ Privacy } & p1: My privacy will get harm over the Internet (Reverse coding) & 3.18 & 0.99 \\
\hline & p2: I do not trust PSSs about preserving my privacy (Reverse coding) & 3.03 & 1.01 \\
\hline \multirow{2}{*}{ Security } & s1: It is safe using credit cards while shopping from PSSs & 3.32 & 0.88 \\
\hline & s2: Generally making payment on Internet is reliable & 3.15 & 0.91 \\
\hline \multirow{8}{*}{$\begin{array}{l}\text { System } \\
\text { quality }\end{array}$} & syq1: My favourite PSS* has a convenient design & 3.85 & 0.74 \\
\hline & syq2: My favourite PSS has an easy navigation for reaching information & 3.88 & 0.69 \\
\hline & syq3: My favourite PSS has a quick response and operation process & 3.82 & 0.75 \\
\hline & syq4: My favourite PSS provides a reliable sale process & 3.58 & 0.84 \\
\hline & syq5: I can use my favourite PSS whenever I want & 4.15 & 0.67 \\
\hline & syq6: My favourite PSS, has a well functionality related to its site type & 3.87 & 0.77 \\
\hline & syq7: My favourite PSS provides error-free processes & 3.44 & 0.87 \\
\hline & syq8: My favourite PSS, provides a convenient audio-visual presentation & 3.77 & 0.78 \\
\hline \multirow{8}{*}{$\begin{array}{l}\text { Information } \\
\text { quality }\end{array}$} & iq1: My favourite PSS has the satisfactory content that I expect & 3.53 & 0.87 \\
\hline & iq2: My favourite PSS provides complete information & 3.31 & 0.91 \\
\hline & iq3: My favourite PSS provides detailed information & 3.30 & 0.92 \\
\hline & iq4: My favourite PSS provides accurate information & 3.40 & 0.84 \\
\hline & iq5: My favourite PSS provides current information & 3.57 & 0.81 \\
\hline & iq6: My favourite PSS provides reliable information & 3.38 & 0.84 \\
\hline & iq7: My favourite PSS transmits the information in an appropriate format & 3.59 & 0.80 \\
\hline & iq8: My favourite PSS provides comparable information among products & 3.50 & 1.00 \\
\hline
\end{tabular}


Table 6 continued

\begin{tabular}{llll}
\hline Scale & Scale items & Mean & $\begin{array}{l}\text { Standard } \\
\text { deviation }\end{array}$ \\
\hline \multirow{4}{*}{ Service } & seq1: My favourite PSS is ready for user requests and meets the requests quickly & 3.50 & 0.85 \\
Quality & seq2: I trust my favourite PSS about keeping its promises & 3.41 & 0.88 \\
& seq3: My favourite PSS builds up trust for users and minimizes the uncertainty & 3.42 & 0.86 \\
& seq4: My favourite PSS understands the users and adapts to their individual needs & 3.36 & 0.86 \\
& seq5: My favourite PSS provides an adequate order follow-up service to users & 3.80 & 0.80 \\
\hline \multirow{2}{*}{ Product } & seq6: My favourite PSS projects a professional and qualified image & 3.67 & 0.80 \\
\hline & pq1: My favourite PSS offers products with high quality & 3.22 & 0.91 \\
& pq2: My favourite PSS offers products with high variety & 3.98 & 0.71 \\
pq3: My favourite PSS offers original products of brands & 3.63 & 0.90 \\
\hline \multirow{2}{*}{ selivery } & ds1: My favourite PSS delivers ordered products correctly & 3.76 & 0.86 \\
& ds2: My favourite PSS delivers securely-packed products & 3.82 & 0.86 \\
& ds4: My favourite PSS delivers products at the promised time & 3.62 & 0.96 \\
\hline
\end{tabular}

In order to test hypotheses, regression analysis has been made. Following tables and explanations below them show the regression analysis results.

Table 7

Product Quality and Perceived Usefulness Relationship

\begin{tabular}{llllll}
\hline Model & B & Std. error & Beta $(\beta)$ & $t$ & Sig. $(p)$ \\
\hline Constant & 1.669 & 0.175 & & 9.560 & 0.000 \\
Product quality & 0.547 & 0.048 & 0.495 & 11.497 & 0.000 \\
$\mathrm{R}=0.495 \mathrm{R}^{2}=0.245$ Adjusted $\mathrm{R}^{2}=0.243$ & & & & \\
$\mathrm{~F}=132.18 p=0.000$ & & & & \\
\hline
\end{tabular}

Dependent variable: perceived usefulness.

Model which shows the relationship between product quality and perceived usefulness provides a good fit ( $\mathrm{F}=132.18, p<0.05)$. The independent variable (product quality) reliably predicts the dependent variable (perceived usefulness). $\mathrm{R}^{2}$ value indicates that $24.5 \%$ of the variance in perceived usefulness can be predicted from the product quality. Besides, there is a statistically significant relationship between product quality (one of PSS's offline characteristic) and PSS's perceived usefulness $(t=11.497, p<0.05)$. So $H 1$ is accepted.

Table 8

Delivery Service and Perceived Usefulness Relationship

\begin{tabular}{llllll}
\hline Model & B & Std. error & Beta $(\beta)$ & $t$ & Sig. $(p)$ \\
\hline Constant & 2.085 & 0.167 & & 12.483 & 0.000 \\
Delivery service & 0.425 & 0.045 & 0.427 & 9.519 & 0.000 \\
$\mathrm{R}=0.427 \mathrm{R}^{2}=0.182$ Adjusted $\mathrm{R}^{2}=0.180$ & & & & \\
$\mathrm{~F}=90.61 \mathrm{p}=0.000$ & & & & \\
\hline
\end{tabular}

Dependent variable: perceived usefulness.

Model which shows the relationship between delivery service and perceived usefulness provides a good fit $(\mathrm{F}=90.61, p<0.05)$. The independent variable (delivery service) reliably predicts the dependent variable (perceived usefulness). $\mathrm{R}^{2}$ value indicates that $18.2 \%$ of the variance in perceived usefulness can be 
predicted from the delivery service. Besides, there is a statistically significant relationship between delivery service (one of PSS's offline characteristic) and PSS's perceived usefulness $(t=9.519, p<0.05$ ). So $H 2$ is accepted.

Table 9

System Quality and Perceived Usefulness Relationship

\begin{tabular}{llllll}
\hline Model & B & Std. error & Beta $(\beta)$ & $t$ & Sig. $(p)$ \\
\hline Constant & 1.118 & 0.210 & & 5.326 & 0.000 \\
System quality & 0.666 & 0.055 & 0.516 & 12.166 & 0.000 \\
$\mathrm{R}=0.516 \mathrm{R}^{2}=0.267$ Adjusted $\mathrm{R}^{2}=0.265$ & & & & \\
$\mathrm{~F}=148.00 p=0.000$ & & & & \\
\hline
\end{tabular}

Dependent variable: perceived usefulness.

Model which shows the relationship between system quality and perceived usefulness provides a good fit ( $\mathrm{F}=148.00, p<0.05$ ). The independent variable (system quality) reliably predicts the dependent variable (perceived usefulness). $\mathrm{R}^{2}$ value indicates that $26.7 \%$ of the variance in perceived usefulness can be predicted from the system quality. Besides, there is a statistically significant relationship between system quality (one of PSS's online characteristic) and PSS's perceived usefulness ( $t=12.166, p<0.05)$. So $H 3$ is accepted.

Table 10

Information Quality and Perceived Usefulness Relationship

\begin{tabular}{llllll}
\hline Model & $\mathrm{B}$ & Std. error & Beta $(\beta)$ & $t$ & Sig. $(p)$ \\
\hline Constant & 2.023 & 0.163 & & 12.371 & 0.000 \\
Information quality & 0.470 & 0.046 & 0.448 & 10.118 & 0.000 \\
$\mathrm{R}=0.448 \mathrm{R}^{2}=0.201$ Adjusted $\mathrm{R}^{2}=0.199$ & & & & \\
$\mathrm{~F}=102.38 p=0.000$ & & & & \\
\hline
\end{tabular}

Dependent variable: perceived usefulness.

Model which shows the relationship between information quality and perceived usefulness provides a good fit $(\mathrm{F}=102.38, \mathrm{p}<0.05)$. The independent variable (information quality) reliably predicts the dependent variable (perceived usefulness). $\mathrm{R}^{2}$ value indicates that $20.1 \%$ of the variance in perceived usefulness can be predicted from the information quality. Besides, there is a statistically significant relationship between information quality (one of PSS's online characteristic) and PSS's perceived usefulness $(t=10.118, p<0.05)$. So $H 4$ is accepted.

Table 11

Service Quality and Perceived Usefulness Relationship

\begin{tabular}{llllll}
\hline Model & B & Std. error & Beta $(\beta)$ & $t$ & Sig. $(p)$ \\
\hline Constant & 1.828 & 0.167 & & 10.958 & 0.000 \\
Service quality & 0.515 & 0.046 & 0.482 & 11.090 & 0.000 \\
$\mathrm{R}=0.482 \mathrm{R}^{2}=0.232$ Adjusted $\mathrm{R}^{2}=0.230$ & & & & \\
$\mathrm{~F}=122.98 p=0.000$ & & & & \\
\hline
\end{tabular}

Dependent variable: perceived usefulness.

Model which shows the relationship between service quality and perceived usefulness provides a good fit ( $\mathrm{F}=122.98, p<0.05)$. The independent variable (service quality) reliably predicts the dependent variable (perceived usefulness). $\mathrm{R}^{2}$ value indicates that $23.2 \%$ of the variance in perceived usefulness can be predicted 
from the service quality. Besides, there is a statistically significant relationship between service quality (one of PSS's online characteristic) and PSS's perceived usefulness $(t=11.09, p<0.05)$. So H5 is accepted.

Table 12

System Quality and Perceived Ease of Use Relationship

\begin{tabular}{llllll}
\hline Model & B & Std. error & Beta $(\beta)$ & $t$ & Sig. $(p)$ \\
\hline Constant & 1.309 & 0.248 & & 5.291 & 0.000 \\
System quality & 0.717 & 0.065 & 0.483 & 11.120 & 0.000 \\
$\mathrm{R}=0.483 \mathrm{R}^{2}=0.233$ Adjusted $\mathrm{R}^{2}=0.231$ & & & & \\
$\mathrm{~F}=123.65 p=0.000$ & & & & \\
\hline
\end{tabular}

Dependent variable: perceived ease of use.

Model which shows the relationship between system quality and perceived ease of use provides a good fit $(\mathrm{F}=123.65, p<0.05)$. The independent variable (system quality) reliably predicts the dependent variable (perceived ease of use). $\mathrm{R}^{2}$ value indicates that $23.3 \%$ of the variance in perceived ease of use can be predicted from the system quality. Besides, there is a statistically significant relationship between system quality (one of PSS's online characteristic) and PSS's perceived ease of use $(t=11.12, p<0.05)$. So H6 is accepted.

Table 13

Information Quality and Perceived Ease of Use Relationship

\begin{tabular}{llllll}
\hline Model & $\mathrm{B}$ & Std. error & Beta $(\beta)$ & $t$ & Sig. $(p)$ \\
\hline Constant & 2.487 & 0.196 & & 12.698 & 0.000 \\
Information quality & 0.448 & 0.056 & 0.370 & 8.045 & 0.000 \\
$\mathrm{R}=0.370 \mathrm{R}^{2}=0.137$ Adjusted $\mathrm{R}^{2}=0.135$ & & & & \\
$\mathrm{~F}=64.73 p=0.000$ & & & & \\
\hline
\end{tabular}

Dependent variable: perceived ease of use.

Model which shows the relationship between information quality and perceived ease of use provides a good fit ( $\mathrm{F}=64.73, p<0.05)$. The independent variable (information quality) reliably predicts the dependent variable (perceived ease of use). $\mathrm{R}^{2}$ value indicates that $13.7 \%$ of the variance in perceived ease of use can be predicted from the information quality. Besides, there is a statistically significant relationship between information quality (one of PSS's online characteristic) and PSS's perceived ease of use $(t=8.045, p<0.05)$. So $H 7$ is accepted.

Table 14

Service Quality and Perceived Ease of Use Relationship

\begin{tabular}{llllll}
\hline Model & $\mathrm{B}$ & Std. error & Beta $(\beta)$ & $t$ & Sig. $(p)$ \\
\hline Constant & 2.310 & 0.202 & & 11.466 & 0.000 \\
Service quality & 0.488 & 0.056 & 0.396 & 8.700 & 0.000 \\
$\mathrm{R}=0.396 \mathrm{R}^{2}=0.157$ Adjusted $\mathrm{R}^{2}=0.155$ & & & & \\
$\mathrm{~F}=75.695 p=0.000$ & & & & \\
\hline
\end{tabular}

Dependent variable: perceived ease of use.

Model which shows the relationship between service quality and perceived ease of use provides a good fit $(\mathrm{F}=75.69, p<0.05)$. The independent variable (service quality) reliably predicts the dependent variable (perceived ease of use). $\mathrm{R}^{2}$ value indicates that $15.7 \%$ of the variance in perceived ease of use can be predicted from the service quality. Besides, there is a statistically significant relationship between service 
quality (one of PSS's online characteristic) and PSS's perceived ease of use $(t=8.70, p<0.05)$. So $H 8$ is accepted.

Table 15

Perceived Ease of Use and Perceived Usefulness Relationship

\begin{tabular}{llllll}
\hline Model & B & Std. error & Beta $(\beta)$ & $t$ & Sig. $(p)$ \\
\hline Constant & 1.966 & 0.155 & & 12.656 & 0.000 \\
Perceived ease of use & 0.416 & 0.038 & 0.480 & 11.035 & 0.000 \\
$\mathrm{R}=0.480 \mathrm{R}^{2}=0.230$ Adjusted $\mathrm{R}^{2}=0.228$ & & & & \\
$\mathrm{~F}=121.767 p=0.000$ & & & & \\
\hline
\end{tabular}

Dependent variable: perceived usefulness.

Model which shows the relationship between perceived ease of use and perceived usefulness provides a good fit $(\mathrm{F}=121.76, p<0.05)$. The independent variable (perceived ease of use) reliably predicts the dependent variable (perceived usefulness). $\mathrm{R}^{2}$ value indicates that $23 \%$ of the variance in perceived usefulness can be predicted from the perceived ease of use. Besides, there is a statistically significant relationship between PSS's perceived ease of use and PSS's perceived usefulness $(t=11.03, p<0.05)$. So $H 9$ is accepted.

Table 16

Perceived Usefulness and Attitude Relationship

\begin{tabular}{llllll}
\hline Model & B & Std. error & Beta $(\beta)$ & $t$ & Sig. $(p)$ \\
\hline Constant & 1.231 & 0.121 & & 10.200 & 0.000 \\
Perceived usefulness & 0.681 & 0.032 & 0.721 & 20.983 & 0.000 \\
$\mathrm{R}=0.721 \mathrm{R}^{2}=0.520$ Adjusted $\mathrm{R}^{2}=0.518$ & & & & \\
$\mathrm{~F}=440.275 p=0.000$ & & & & \\
\hline
\end{tabular}

Dependent variable: attitude.

Model which shows the relationship between perceived usefulness and attitude provides a good fit $(\mathrm{F}=$ 440.275, $p<0.05$ ). The independent variable (perceived usefulness) reliably predicts the dependent variable (attitude). $\mathrm{R}^{2}$ value indicates that $52 \%$ of the variance in attitude can be predicted from the perceived usefulness. Besides, there is a statistically significant relationship between PSS's perceived usefulness and consumers's attitudes towards shopping from PSS $(t=20.983, p<0.05)$. So $H 10$ is accepted.

Table 17

Perceived Ease of Use and Attitude Relationship

\begin{tabular}{llllll}
\hline Model & B & Std. error & Beta $(\beta)$ & $t$ & Sig. $(p)$ \\
\hline Constant & 2.047 & 0.145 & & 14.168 & 0.000 \\
Perceived ease of use & 0.413 & 0.035 & 0.504 & 11.773 & 0.000 \\
$\mathrm{R}=0.504 \mathrm{R}^{2}=0.254$ Adjusted $\mathrm{R}^{2}=0.252$ & & & & \\
$\mathrm{~F}=138.599 p=0.000$ & & & & \\
\hline
\end{tabular}

Dependent variable: attitude.

Model which shows the relationship between perceived ease of use and attitude provides a good fit ( $\mathrm{F}=$ $138.59, p<0.05$ ). The independent variable (perceived ease of use) reliably predicts the dependent variable (attitude). $\mathrm{R}^{2}$ value indicates that $25.4 \%$ of the variance in attitude can be predicted from the perceived ease of use. Besides, there is a statistically significant relationship between PSS's perceived ease of use and consumers's attitudes towards shopping from PSS $(t=11.773, p<0.05)$. So $H 11$ is accepted. 
Table 18

Compatibility and Attitude Relationship

\begin{tabular}{llllll}
\hline Model & B & Std. error & Beta $(\beta)$ & $t$ & Sig. $(p)$ \\
\hline Constant & 1.897 & 0.092 & & 20.508 & 0.000 \\
Compatibility & 0.529 & 0.026 & 0.710 & 20.333 & 0.000 \\
$\mathrm{R}=0.710 \mathrm{R}^{2}=0.504$ Adjusted $\mathrm{R}^{2}=0.503$ & & & & \\
$\mathrm{~F}=413.414 p=0.000$ & & & & \\
\hline
\end{tabular}

Dependent variable: attitude.

Model which shows the relationship between compatibility and attitude provides a good fit $(\mathrm{F}=413.41, p$ $<0.05$ ). The independent variable (compatibility) reliably predicts the dependent variable (attitude). $\mathrm{R}^{2}$ value indicates that $50.4 \%$ of the variance in attitude can be predicted from the compatibility. Besides, there is a statistically significant relationship between consumers' beliefs on PSS's compatibility and consumers' attitudes towards shopping from PSS $(t=20.33, p<0.05)$. So $H 12$ is accepted.

Table 19

Privacy and Attitude Relationship

\begin{tabular}{llllll}
\hline Model & B & Std. error & Beta $(\beta)$ & $t$ & Sig. $(p)$ \\
\hline Constant & 3.182 & 0.117 & & 27.244 & 0.000 \\
Privacy & 0.171 & 0.036 & 0.229 & 4.740 & 0.000 \\
$\mathrm{R}=0.229 \mathrm{R}^{2}=0.052$ Adjusted $\mathrm{R}^{2}=0.050$ & & & & \\
$\mathrm{~F}=22.463 p=0.000$ & & & & \\
\hline
\end{tabular}

Dependent variable: attitude.

Model which shows the relationship between privacy and attitude provides a good fit ( $\mathrm{F}=22.46, p<0.05$ ). The independent variable (privacy) reliably predicts the dependent variable (attitude). $\mathrm{R}^{2}$ value indicates that $5.2 \%$ of the variance in attitude can be predicted from the privacy. Besides, there is a statistically significant relationship between consumers' beliefs on the privacy provided by PSS and consumers' attitudes towards shopping from PSS $(t=4.740, p<0.05)$. So $H 13$ is accepted.

Table 20

Security and Attitude Relationship

\begin{tabular}{llllll}
\hline Model & B & Std. error & Beta $(\beta)$ & $t$ & Sig. $(p)$ \\
\hline Constant & 2.778 & 0.130 & & 21.345 & 0.000 \\
Security & 0.290 & 0.039 & 0.345 & 7.415 & 0.000 \\
$\mathrm{R}=0.345 \mathrm{R}^{2}=0.119$ Adjusted $\mathrm{R}^{2}=0.117$ & & & & \\
$\mathrm{~F}=54.988 p=0.000$ & & & & \\
\hline
\end{tabular}

Dependent variable: attitude.

Model which shows the relationship between security and attitude provides a good fit $(\mathrm{F}=54.98, p<0.05)$. The independent variable (security) reliably predicts the dependent variable (attitude). $\mathrm{R}^{2}$ value indicates that $11.9 \%$ of the variance in attitude can be predicted from the security. Besides, there is a statistically significant relationship between consumers' beliefs on PSS's security and consumers' attitudes towards shopping from $\operatorname{PSS}(t=7.415, p<0.05)$. So $H 14$ is accepted.

\section{Conclusions}

Online shopping offers customers a lot of advantages such as shopping convenience, information 
gathering ease, time saving, wide product variety, price comparision ease, being away from crowd, and cheaper prices etc. (Thain \& Bradley, 2012). However online shopping is still seen as risky from customers' viewpoint. So in all countries the share of online retailing in total retailing is small (generally lower than $10 \%$, see Table 1). For that reason understanding online customers is very critical for online retailers. With the help of this understanding they can encourage these customers to increase their share of wallet. Although this situation is valid for all types of online retailing including PSSs, in the literature there are very limited number of studies researching PSS customers. So, the aim of this study is exhibiting variables affecting attitudes of PSS customers and conceptualizing these variables under a model that depends on TAM. Fourteen hypotheses are developed form this model and they are tested via regression analysis which resulted in the acceptence of all hypotheses. In other words, all of the relationships in the model are statistically significant. The highest variance prediction percentages belong to perceived usefulness \& attitude (52\%) and compatibility \& attitude (50.4\%) respectively. Conversely the lowest variance prediction percentage belongs to privacy \& attitude (5.2\%). In fact it does not mean that privacy is not important for online shoppers in Turkey. Privacy is being protected by laws, and companies are not able to send marketing messages without permission of customers. So, protecting privacy has already become a standard for companies and does not differentiate them.

According to these results, it can be said that the most important determinants in building positive attitudes towards PSSs are perceived usefulness and compatibility. So, first of all, PSSs should facilitate making comparison shopping, and provide useful shopping information, time \& money saving, better buying decisions, and fashion following. Also PSSs should be very compatible to their target customers' lifestyle and their shopping needs. Also, it should be underlined that there is a great potential in Turkey for the PSSs as it can be understood from the overview of online shopping in Turkey at the beginning of this study.

\section{Directions for Future Research}

There are several research opportunities due to the limited literature on PSS customers' attitudes. Firstly, same model can be tested on a more diversified sample. In this study most of the participants are women (77.8\%) and $75.8 \%$ of them are under 35 years old. Besides almost all of the participants (99\%) have bachelor's degree at least. Secondly, this study did not focus on any product category although PSSs sell various products such as apparels, electronics, cosmetics, home textile, shoes, bags, and accessories. In a future study, the model can be tested on different product category and results can be compared. In this case, most important determinants in building positive attitudes towards PSSs can change between different product categories. Thirdly, comparing PSS users with non-users by testing the model of this study can produce interesting results. Fourthly, the same model can be tested for the other online retailing types apart from PSSs and then comparisions can be made. The last recommendation is about cross-cultural studies. Different countries have different usage rates in online shopping. So testing this model in several countries and comparing consumer attitudes can be meaningful. Nevertheless, because of the dynamic nature of the Internet, it can be estimated that PSSs will be developed by new features in a near future. So new variables can be added to (or existing ones can be excluded from) the model in future researches.

\section{Limitations}

There are millions of PSS customers in Turkey; however because of time constraints only 409 questionnaires could be analyzed. This limited number of the sample is one of the limitation. Also 
characteristics of individuals within this sample are very similar because of the sampling method. As in all non-random sampling methods, snowball sampling causes systematic errors (Özmen, 2006). So representativeness of this sample is constricted and a more diversified sample will increase the generalizability of the model to the population. In short, the quality and quantity of the sample are the main weaknesses of this study. However it should be noted that dominance of women participants (77.8\%) is not a limitation, and in contrast it increases the representativeness. Seventy-five of Markafoni's sales derive from women (http://www.superbrandsturkey.com/markalar/Markafoni/markafon-tr.pdf). Another limitation is ignoring the indirect impacts between the variables in order to simplify the model. For instance impact of security on perceived usefulness or impact of privacy on security can be added to model in order to find significant relationships.

\section{Acknowledgements}

I would like to thank all those people who made this study which evolved out of my Ph.D. thesis possible. First of all, I express my deepest sense of gratitude to my supervisor Prof. Mehmet Tiğlı from Marmara University who offered his continuous advice and encouragement throughout my thesis process. Also I thank Prof. Serdar Pirtini and Prof. Özgür Çengel, my thesis committee members, for their systematic guidance and great efforts.

\section{References}

Ahn, T., Ryu, S., \& Han, I. (2004). The impact of the online and offline features on the user acceptance of internet shopping malls. Electronic Commerce Research and Applications, 3, 405-420.

Akalın, S. (2011). Determinants of purchase behavior towards private shopping websites: A consumer-based model incorporating website features, consumer-centric indicators and sales promotions. Retrieved from https://tez.yok.gov.tr/UlusalTezMerkezi/giris.jsp

Ayadi, N., Giraud, M., \& Gonzalez, C. (2013). An investigation of consumers' self-control mechanisms when confronted with repeated purchase temptations: Evidence from online private sales. Journal of Retailing and Consumer Services, 20, 272-281.

Büyüköztürk, Ş. (2011). Sosyal bilimler için veri analizi el kitabı: Istatistik, araştırma deseni, SPSS uygulamaları ve yorum. Ankara: Pegem Akademi Yayıncılık.

Chen, L., Gillenson, M. L., \& Sherrell, D. L. (2002). Enticing online consumers: An extended technology acceptance perspective. Information \& Management, 39(8), 705-719.

Davis, F. D. (1986). A technology acceptance model for empirically testing new end-user information systems: Theory and results. Retrieved from http://dspace.mit.edu/handle/1721.1/15192

Davis, F. D. (1989). Usefulness, perceived ease of use, and user acceptance of information technology. MIS Quarterly, 13(3), 319-340.

Davis, F. D., Bagozzi, R. P., \& Warshaw, P. R. (1989). User acceptance of computer technology: A comparison of two theoretical models. Management Science, 35(8), 982-1003.

İnci, B. (2014). Consumer perceptions and buying behaviors towards "private shopping site" business model as an online retailing method. Retrieved from https://tez.yok.gov.tr/UlusalTezMerkezi/giris.jsp

Lin, H. F. (2007). Predicting consumer intentions to shop online: An empirical test of competing theories. Electronic Commerce Research and Applications, 6, 433-442.

Martinez, B. M. (2011). An analysis of the impacts of consumer shopping characteristics and perceived website quality on purchase intention from a private sales $\quad$ site. $\quad$ Retrieved from https://getd.libs.uga.edu/pdfs/martinez_briana_m_201105_ms.pdf

Martinez, B., \& Kim, S. (2012). Predicting purchase intention for private sale sites. Journal of Fashion Marketing and Management, 16(3), 342-365.

Özmen, A. (2006). İstatistik. Anadolu Üniversitesi Yayını (No. 1448). Açıköğretim Fakültesi Yayını (No. 771). Eskişehir. 
Thain, G., \& Bradley, J. (2012). Store wars: The worldwide battle for mindspace and shelfspace, online and in-store (2nd ed.). NJ. USA: Wiley.

Turkstat (Turkish Statistical Institute)'s Information and Communication Technology (ICT) Usage Survey on Households and Individuals. (2016). Report. Retrieved from http://www.turkstat.gov.tr/PreHaberBultenleri.do?id=21779

Turkstat 2016 Data. (2016). Retrieved from http://www.tuik.gov.tr/PreHaberBultenleri.do?id=21507

TÜBISAD. (2015). Turkey's E-Trade Industry-2015 Report. $\quad$ Retrieved from https://www2.deloitte.com/content/dam/Deloitte/tr/Documents/technology-media-telecommunications/TUBISAD-Eticaret-2 015-Sunum.pdf

Vijayasarathy, L. R. (2004). Predicting consumer intentions to use online shopping: The case for an augmented Technology Acceptance Model. Information \& Management, 41, 747-762. 